\title{
UNVEILING THE CORE COMPETENCIES OF THE SUCCESSFUL PROJECT MANAGER THROUGH THE APPLICATION OF MULTIOBJECTIVE GENETIC ALGORITHM
}

\section{REVELANDO AS PRINCIPAIS COMPETÊNCIAS DO BEM-SUCEDIDO GERENTE DE PROJETOS POR MEIO DA APLICAÇÃO DO ALGORITMO GENÉTICO MULTIOBJETIVO}

\section{REVELANDO LAS COMPETENCIAS CENTRALES DEL GERENTE DE PROYECTO EXITOSO A TRAVÉS DE LA APLICACIÓN DEL ALGORITMO GENÉTICO MULTIOBJETIVO}

\section{Ralf Luis de Moura:}

Doutorado em Administração pela Universidade Federal do Espírito Santo. Professor dos cursos superiores de Engenharia da Computação, Engenharia Elétrica, Engenharia de Controle e Automação, Ciência da Computação, Sistemas de Informação, Tecnologia em Desenvolvimento de Sistemas, Redes de Computadores e Jogos Digitais no Centro Universitário FAESA.

ralf.luis@faesa.br

https://orcid.org/0000-0002-0170-4056

Teresa Cristina Janes Carneiroteresa.

Doutorado em Administração pelo Instituto COPPEAD/UFRJ. Pró-Reitora de Administração da UFES (2016-2020). Vice-presidente do Fórum Nacional de Programas de Pós-Graduação

Profissionais - FOPROF.

janes.carneiro@gmail.com

https://orcid.org/0000-0001-9987-1460

Marcos Paulo Valadares de Oliveira

Professor Associado do Departamento de Administração da Universidade Federal do Espírito Santo, pesquisador e coordenador do núcleo de pesquisas em Tecnologias e Processos Organizacionais TecPrO e gerente de projetos do Núcleo Interdisciplinar de Pesquisa e Extensão em Logística (NIPELog/UFMG).

marcos.p.oliveira@ufes.br

https://orcid.org/0000-0003-2646-5247

Editor Científico: José Edson Lara
Organização Comitê Científico
Double Blind Review pelo SEER/OJS
Recebido em 05.06.2020
Aprovado em 06.08.2020




\title{
Resumo
}

Objetivo: O objetivo deste estudo exploratório foi encontrar as principais competências dos gerentes de projeto compostas por comportamentos, habilidades e conhecimentos que influenciam o desempenho do projeto através de quatro pilares: custo, qualidade, escopo e tempo.

Metodologia: Uma pesquisa de levantamento com profissionais em gerenciamento de projetos e a análise utiliza o método de seleção de variáveis conhecido como algoritmo genético multiobjetivo.

Originalidade e Relevância: A relevância e originalidade deste estudo está em revelar as principais competências (coletadas de estudo anteriores) que um gerente de projeto precisa ter para que os projetos gerenciados por ele atinjam um maior desempenho.

Principais resultados: Os resultados mostram que as competências estabilidade emocional, comunicação verbal, conhecimento em tópicos multidisciplinares, entre outras, influenciam o desempenho do projeto.

Contribuições metodológicas: Este estudo contribui para a pesquisa científica em ciências sociais, introduzindo o algoritmo genético multiobjetivo como uma técnica alternativa para a seleção de variáveis. Essa técnica reduz o número de variáveis, mantendo o poder explicativo do fenômeno analisado.

Contribuições para gestão: Esses resultados podem ajudar na tomada de decisões ao direcionar esforços para o recrutamento e treinamento de profissionais de gerenciamento de projetos.

Palavras Chave: Algoritmo Genético Multiobjetivo, Competências, Desempenho do Projeto.

\begin{abstract}
Objective: The objective of this exploratory study was to find the core project managers' competencies composed of behaviors, skills, and knowledge that influence the project performance through four pillars: cost, quality, scope, and time.
\end{abstract}

Methodology / approach: A survey with project management professionals and the analysis uses the variable selection method known as the multiobjective genetic algorithm.

Originality / Relevance: The relevance and originality of this study are in revealing the main competencies (collected from previous studies) that a project manager needs to have in order for the projects managed by him to achieve higher performance.

Main Results: The results show that the competencies emotional stability, verbal communication, knowledge on multidisciplinary topics, among others, influence the performance of the project.

Theoretical / Methodological Contributions: This study contributes to scientific research in social sciences, introducing the multiobjective genetic algorithm as an alternative technique for the selection of variables. This technique reduces the number of variables, maintaining the explanatory power of the analyzed phenomenon. 
Management Contributions: These results can assist in decision making by directing efforts towards the recruitment and training of project management professionals.

Keywords: Multiobjective Genetic Algorithm, Core Competencies, Project Performance.

\section{Resumen}

Objetivo: El objetivo de este estudio exploratorio fue encontrar las competencias básicas de los gerentes de proyecto compuestas de comportamientos, habilidades y conocimientos que influyen en el desempeño del proyecto a través de cuatro pilares: costo, calidad, alcance y tiempo.

Metodología / enfoque: una encuesta con profesionales de gestión de proyectos y el análisis utiliza el método de selección de variables conocido como el algoritmo genético multiobjetivo se aplicó para lograr este objetivo.

Originalidad / Relevancia: La relevancia y originalidad de este estudio están en revelar las principales competencias (recopiladas de estudios previos) que un gerente de proyecto necesita tener para que los proyectos administrados por él alcancen un mayor rendimiento.

Resultados principales: Los resultados muestran que las competencias estabilidad emocional, comunicación verbal, conocimiento sobre temas multidisciplinarios, entre otros, influyen en el desempeño del proyecto.

Contribuciones teóricas / metodológicas: este estudio contribuye a la investigación científica en ciencias sociales, presentando el algoritmo genético multiobjetivo como una técnica alternativa para la selección de variables. Esta técnica reduce el número de variables, manteniendo el poder explicativo del fenómeno analizado.

Contribuciones de gestión: estos resultados pueden ayudar en la toma de decisiones al dirigir los esfuerzos hacia la contratación y capacitación de profesionales de gestión de proyectos.

Palabras clave: Algoritmo genético multiobjetivo, Competencias centrales, Rendimiento del proyecto.

\section{Introduction}

Projects are part of organizational activities and influence companies' performance results. Projects arise in organizations for many reasons, and they generate impacts on the organization's results in the short term and long term. There are indications that maturity in project management can have a direct impact on organizations' performance, and improving maturity is a strategy for increasing competitiveness, reducing costs, and improving the organization's revenues (Yazici, 2018).

Increasing maturity in project management also involves improving the competencies of the professional responsible for the performance and deliveries of project results: the project 
manager (PM). According to the Project Management Institute (PMI) (2017), the PM is ultimately responsible for all project's results, whether positive or negative, which indicates the relevance of the abilities of this professional in the outcomes of a project (Kerzner, 2016).

Against a backdrop of intense competition between companies and significant and rapid changes in the competitive environment, it becomes even more critical to understand the characteristics that compose the ideal profile of project management professionals. Thus, to adequately invest in developing the competencies of this professional, it is necessary to answer the following question: What are the core competencies of a project manager that influences the project performance?

The objective of this study is to explore and identify, in the literature, the competencies of the project manager and, based on them, select a set of more relevant (core) ones that influence the project performance.

We researched in the literature the core competencies associated with a PM, and, based on these competencies; we selected the most relevant using the data analysis technique known as genetic algorithms (GA). Due to a large number of different competencies of a project manager, it was necessary to use a technique to select only relevant variables that could compose a parsimonious model keeping the explicative power of the phenomenon. Genetic algorithms are widely applied in chemistry and biology researches to select the smallest set of variables that best explain a particular phenomenon (Kramer, 2017; Sliwoski et al., 2014), but its use is not yet widespread in social science research.

After this brief introduction, it presented the concepts of the project manager's competencies, project performance, and GA. The following section presents the method, followed by the presentation of the results. It developed the data analysis, and then, it presents the final considerations, opening up new research opportunities and discussing the practical implications of the results.

\section{Literature Review}

\subsection{Project Manager}

The PM is the person allocated to the project that leads the team responsible for achieving the project's objectives (PMI, 2017). Organizations assign to the PM the responsibility for conducting and delivering their projects. Among their duties, the PM is in charge of 
coordinating and integrating activities in various technical and functional lines, as well as managing communications between interested parties.

To ensure project delivery, the PM needs to have communication and interpersonal skills, negotiation skills combined with an understanding of the organization's culture, familiarity with the operations of each sector of the organization, and a series of other competencies (Kerzner, 2009; PMI, 2017).

Pinto (2000) states that PMs are in a position where it is necessary to use human (nontechnical) skills, such as bargaining, influence, conflict management, and negotiation to ensure the resources necessary to achieve the project's success. Such skills can be more or less developed (and applied) depending on the project environment and the organization. PMI (2017) argues that the understanding and application of tools and techniques, recognized as good practices, are not sufficient for effective project management, requiring the PM to have other competencies.

The PM is directly responsible for the project results, which indicates this professional's importance (PMI, 2017). Accordingly, there are approaches and efforts in companies for the maturation of PMs, and there is an interest in mapping their competencies (Boyatzis et al., 2019). Therefore, performance based on the development of the manager's competencies implies maximization of project performance (Anantatmula an\& d Rad, 2018; Kerzner, 2016; Moura et al., 2019). There is evidence that some PM's skills, knowledge, and attitudes affect project performance at different levels (Moura, Carneiro \& Diniz, 2017).

Through these arguments, the hypothesis of this study is $\mathbf{H}_{1}$ : There is a set of competencies of the PM that have higher relevance in the project's performance, represented by Figure 1.

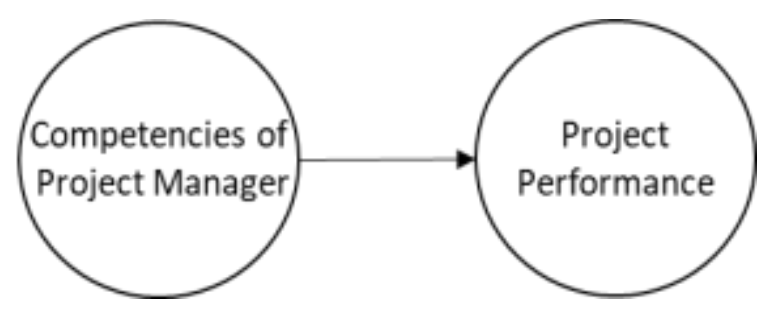

Figure 1. Theoretical Model 


\subsection{Competencies}

The theme of competence in academic and entrepreneurial discussions is abundant, many scholars, such as Durand (2015), Zarifian (2003), Le Boterf (2003), and Dutra (2001), have published classical studies related to competencies and the management of competencies. However, there is no consensus on the definition of competence. A great deal of theoretical debate still occurs in various schools, such as the American and European schools (Fleury and Fleury, 2001). Despite a common core, such debates have different levels of understanding, which hinders consensus.

A theoretical trend supported by Zarifian (2003) considers competence as the ability to take the initiative, the ability to have a practical understanding of situations based on knowledge, and the ability to mobilize a network of actors and make them share actions and responsibilities. Le Boterf (2003) argues that competence is not a state but an action, the result of a set of personal resources such as knowledge, skills, qualities, experience, and cognitive skills, among others. Another theoretical trend (Dutra, 2001; Durand, 2015) describes competence in three dimensions: a set of knowledge, skills, and attitudes that includes technical issues, cognition, and attitudes.

In a study on the PM, his role and skills, Sbragia et al. (1986) argue that much of a project's success depends on the PM's possession of a unique set of aptitudes, classified into three families: knowledge (what the individual knows), attitudes (what he thinks about himself, his work, and other aspects of the environment), and skills (what he can do).

Many studies have shown that when attitudes and personality traits work together, they are indeed a forecast of specific individual behaviors (Winson, 2014). According to major studies in psychology (Erthal, 1984), attitudes and personality traits are therefore closely linked, and together, they can explain behavior.

The understanding of Durand (2015) and Sbragia et al. (1986), as illustrated in Figure 2, who describe competency as a set of knowledge, skills, and behaviors that indicate what the professional knows, his will to want to do something or make something happen and his ability to know how to do something is the base of this study. 


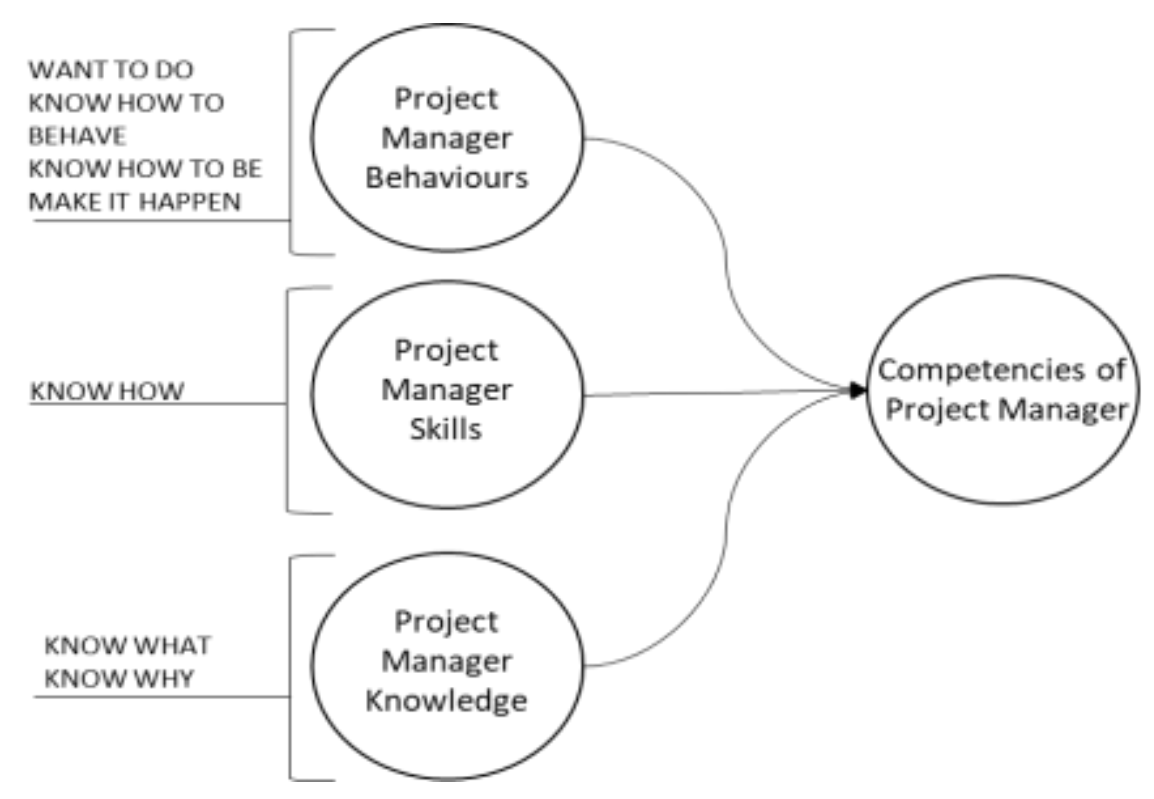

Figure 2. Dimensions of Competence.

Competence is a generic term applied to any professional. For the PM, it has been necessary to find specific studies related to the project management to provide theoretical support for this study.

\subsection{Competencies of Project Manager}

Different studies have analyzed the relationship between the profile of the PM and project success (Fisher, 2011; Moura, Carneiro, and Diniz, 2018). Others have compared functional managers and PMs in terms of profile, attributes, and experiences (El-Sabaa, 2001; Moura et al., 2019) and have also identified the areas of knowledge and the profile required for PMs in areas such as construction (Edum-Fotew \& Mccaffer, 2000; Lampel 2001). However, there is not a consensus about the more relevant competencies.

We conducted a systematic literature review based on original guidelines proposed by Kichenham (2004) to identify the main professional competencies of a PM. The search process was a manual search of relevant journals and conference proceedings papers since 2000 . We choose a more extended period to cover a more significant number of variables. The research included journals and conferences related to the theme, such as International Journal of Project Management, Journal of Research in Personality and Academy of Management Journal. 
The three tables $(1,2$, and 3$)$ below summarize the results of the systematic review, dividing the competencies found in specialized publications into the three dimensions already discussed: knowledge, skills, and behaviors.

Table 1

The Project Manager's Knowledge

\begin{tabular}{|c|c|c|c|}
\hline Topics & & Knowledge & \multirow{2}{*}{ Authors } \\
\hline About ... & \multicolumn{2}{|r|}{ Knowledge of ... } & \\
\hline \multirow{6}{*}{ projects } & $\mathrm{V}_{1}$ & project estimates & Lampel (2001) \\
\hline & $\mathrm{V}_{2}$ & $\begin{array}{l}\text { the techniques and tools for } \\
\text { project management }\end{array}$ & $\begin{array}{l}\text { Haggerty (2000); Lampel (2001); Fotwe and } \\
\text { McCaffer (2000); Brill, Bishop, and Walker } \\
\text { (2006) }\end{array}$ \\
\hline & $\mathrm{V}_{3}$ & the project domain & \multirow{4}{*}{ Brill et al. (2006) } \\
\hline & $\mathrm{V}_{4}$ & the project's mission & \\
\hline & $\mathrm{V}_{5}$ & $\begin{array}{l}\text { the measures of the project's } \\
\text { success }\end{array}$ & \\
\hline & $\mathrm{V}_{6}$ & writing proposals & \\
\hline \multirow{4}{*}{$\begin{array}{l}\text { the organization } \\
\text { and its context }\end{array}$} & $\mathrm{V}_{7}$ & the business & Haggerty (2000); Fotwe and McCaffer (2000) \\
\hline & $\mathrm{V}_{8}$ & the partners & Brill et al. (2006); Lampel (2001) \\
\hline & $\mathrm{V}_{9}$ & $\begin{array}{l}\text { the decision-making process } \\
\text { outside the organization }\end{array}$ & \multirow{2}{*}{ Brill et al. (2006) } \\
\hline & $\mathrm{V}_{10}$ & $\begin{array}{l}\text { the politics or culture outside } \\
\text { the organization }\end{array}$ & \\
\hline \multirow{3}{*}{ technical topics } & $\mathrm{V}_{11}$ & technology assets & \multirow{2}{*}{ Lampel (2001) } \\
\hline & $\mathrm{V}_{12}$ & multidisciplinary subjects & \\
\hline & $\mathrm{V}_{13}$ & computer use & El-Sabaa (2001) \\
\hline
\end{tabular}

Table 2

The Project Manager's Skills

\begin{tabular}{|c|c|c|c|}
\hline Topics & & Skills & \multirow{2}{*}{ Authors } \\
\hline In ... & & Know how to ... & \\
\hline \multirow{5}{*}{ personal issues } & $\mathrm{V}_{14}$ & learn & Lampel (2001) \\
\hline & $\mathrm{V}_{15}$ & create and innovate & $\begin{array}{l}\text { Fotwe and McCaffer (2000); CBO (2019); Kerzner } \\
\text { (2016) }\end{array}$ \\
\hline & $\mathrm{V}_{16}$ & reason analytically & Fotwe and McCaffer (2000) \\
\hline & $\mathrm{V}_{17}$ & reason logically & \multirow{2}{*}{ CBO (2019) } \\
\hline & $\mathrm{V}_{18}$ & adapt to changes & \\
\hline \multirow{5}{*}{ managerial topics } & $\mathrm{V}_{19}$ & $\begin{array}{l}\text { manage tasks } \\
\text { effectively }\end{array}$ & Fotwe and McCaffer (2000); Lampel (2001) \\
\hline & $\mathrm{V}_{20}$ & lead meetings & \multirow{2}{*}{ CBO (2019) } \\
\hline & $\mathrm{V}_{21}$ & negotiate and persuade & \\
\hline & $\mathrm{V}_{22}$ & delegate & CBO (2019); El-Sabaa (2001) \\
\hline & $\mathrm{V}_{23}$ & $\begin{array}{l}\text { be guided through a } \\
\text { problem }\end{array}$ & El-Sabaa (2001); Brill et al. (2006) \\
\hline
\end{tabular}




\begin{tabular}{|c|c|c|c|}
\hline Topics & & Skills & \multirow{2}{*}{ Authors } \\
\hline In ... & \multicolumn{2}{|r|}{ Know how to ... } & \\
\hline & $\mathrm{V}_{24}$ & be guided by a goal & El-Sabaa (2001) \\
\hline & $\mathrm{V}_{25}$ & $\begin{array}{l}\text { place the focus on the } \\
\text { customer }\end{array}$ & Fotwe and McCaffer (2000) \\
\hline \multirow{3}{*}{ practices } & $\mathrm{V}_{26}$ & $\begin{array}{l}\text { evaluate complex } \\
\text { situations }\end{array}$ & Lampel (2001) \\
\hline & $\mathrm{V}_{27}$ & recognize a problem & \multirow{2}{*}{ Brill et al. (2006) } \\
\hline & $\mathrm{V}_{28}$ & apply laws to contracts & \\
\hline $\begin{array}{l}\text { relationships with } \\
\text { stakeholders }\end{array}$ & $\mathrm{V}_{29}$ & $\begin{array}{l}\text { visualize the project's } \\
\text { relationship with the } \\
\text { industry and the } \\
\text { community }\end{array}$ & El-Sabaa (2001) \\
\hline \multirow{3}{*}{ communication } & $\mathrm{V}_{30}$ & communicate verbally & Fisher (2011); El-Sabaa (2001) \\
\hline & $\mathrm{V}_{31}$ & $\begin{array}{l}\text { communicate } \\
\text { graphically }\end{array}$ & Brill et al. (2006) \\
\hline & $\mathrm{V}_{32}$ & $\begin{array}{l}\text { communicate } \\
\text { effectively }\end{array}$ & Fotwe and McCaffer (2000); Fisher (2011) \\
\hline entrepreneurship & $\mathrm{V}_{33}$ & $\begin{array}{l}\text { detect and develop } \\
\text { opportunities }\end{array}$ & Lampel (2001) \\
\hline
\end{tabular}

Behaviour is a dimension of competency and appears in the specialized literature related to personality traits and attitudes. In the context of competencies, attitudes refer to the professional's behavior (Durand, 2015) and are related to psychological tendencies, memory, and the evaluation of objects or entities (Ajzen, 2005). This study treats attitudes and personality traits as Behaviour.

There is an extensive scientific literature on the subject of personality in psychology and management. Many studies have researched personality traits in various fields such as job performance (Judge \& Zapata, 2015), consumption (Basso, Laimer \& Baseggio, 2015), entrepreneurship (Leutner et al., 2014), and organizations (Bastos \& Marchiori, 2012).

As with competencies, many scholars describe personality and personality traits in various ways. Nicholson (2000) defines personality as "the permanence of character." Buchaman and Huczynski (1997) define personality as "the psychological qualities that influence an individual's typical behavioral patterns distinctively and consciously through different situations over time."

Personality traits are an extensive measurement method used in research related to personality. Personality traits are often measured based on five factors (Big Five). The Big Five is a taxonomy used in the branch of psychology (Goldberg, 1990), which, although not universally accepted, appears consistently in relevant studies related to personality (Credé et al., 2012). The Big Five model organizes an individual's characteristics into five domains: 
openness, conscientiousness, agreeableness, neuroticism, and extraversion (De Raad and Mlacic, 2015).

Table 3 summarizes the specific PM behaviors presented in the systematic literature review and the domains for measuring personality traits.

Table 3

The Behavior of the Project Manager

\begin{tabular}{|c|c|c|c|}
\hline \multirow{2}{*}{ Topics } & \multirow{2}{*}{\multicolumn{2}{|c|}{$\frac{\text { Behaviors }}{\text { Acts to / with / as ... }}$}} & \multirow{2}{*}{ Authors } \\
\hline & & & \\
\hline \multirow[t]{2}{*}{ Leadership } & $\begin{array}{c}\mathrm{V}_{3} \\
4\end{array}$ & avoid and resolve disputes and conflicts & Lampel (2001); Fisher (2011) \\
\hline & $\begin{array}{c}\mathrm{V}_{3} \\
5\end{array}$ & build teams & Fotwe and McCaffer (2000); Fisher (2011) \\
\hline \multirow[t]{5}{*}{$\begin{array}{l}\text { Trust and } \\
\text { motivation }\end{array}$} & $\begin{array}{c}\mathrm{V}_{3} \\
6\end{array}$ & build trust & \multirow{2}{*}{ Fisher (2011) } \\
\hline & $\begin{array}{l}\mathrm{V}_{3} \\
7 \\
\end{array}$ & influence others & \\
\hline & $\begin{array}{l}V_{3} \\
8\end{array}$ & motivation and enthusiasm & Fisher (2011); CBO (2019); Kerzner (2016) \\
\hline & $\begin{array}{l}\mathrm{V}_{3} \\
9 \\
\end{array}$ & conduct business ethically & Brill et al. (2006) \\
\hline & $\begin{array}{l}\mathrm{V}_{4} \\
0\end{array}$ & persistent & El-Sabaa (2001); Kerzner (2016) \\
\hline \multirow[t]{2}{*}{ Emotion } & $\begin{array}{l}\mathrm{V}_{4} \\
1 \\
\end{array}$ & emotional intelligence & Thomas and Mengel (2008) \\
\hline & $\begin{array}{l}\mathrm{V}_{4} \\
2\end{array}$ & high self-esteem & El-Sabaa (2001) \\
\hline \multirow[t]{3}{*}{ Relationships } & $\begin{array}{c}\mathrm{V}_{4} \\
3 \\
\end{array}$ & build organizational relationships & Fotwe and McCaffer (2000); Kerzner (2016) \\
\hline & $\begin{array}{c}\mathrm{V}_{4} \\
4 \\
\end{array}$ & Interacts with other areas & CBO (2019) \\
\hline & $\begin{array}{c}\mathrm{V}_{4} \\
5\end{array}$ & build interpersonal relationships & Thomas and Mengel (2008) \\
\hline \multirow[t]{2}{*}{$\begin{array}{l}\text { Communicatio } \\
\mathrm{n}\end{array}$} & $\begin{array}{c}\mathrm{V}_{4} \\
6 \\
\end{array}$ & listens effectively & Brill et al. (2006) \\
\hline & $\begin{array}{c}\mathrm{V}_{4} \\
7\end{array}$ & good verbal expressions & CBO (2019) \\
\hline \multirow[t]{2}{*}{ Teamwork } & $\begin{array}{c}\mathrm{V}_{4} \\
8 \\
\end{array}$ & a team & Kerzner (2016) \\
\hline & $\begin{array}{c}\mathrm{V}_{4} \\
9\end{array}$ & sharing credit for the success & Brill et al. (2006) \\
\hline \multirow[t]{5}{*}{ Personality } & $\begin{array}{c}\mathrm{V}_{5} \\
0 \\
\end{array}$ & proactivity & CBO (2019); Kerzner (2016) \\
\hline & $\begin{array}{c}\mathrm{V}_{5} \\
1 \\
\end{array}$ & flexibility & \multirow{2}{*}{ El-Sabaa (2001) } \\
\hline & $\begin{array}{c}V_{5} \\
2 \\
\end{array}$ & organized & \\
\hline & $\begin{array}{l}\mathrm{V}_{5} \\
3 \\
\end{array}$ & openness to experience & \multirow[t]{2}{*}{ Soto and John (2009) } \\
\hline & $\begin{array}{l}\mathrm{V}_{5} \\
4\end{array}$ & conscientiousness & \\
\hline
\end{tabular}




\begin{tabular}{|c|c|c|c|}
\hline \multirow{5}{*}{ Topics } & & Behaviors & \multirow{5}{*}{ Authors } \\
\hline & \multicolumn{2}{|r|}{ Acts to / with / as ... } & \\
\hline & $\begin{array}{c}\mathrm{V}_{5} \\
5\end{array}$ & neuroticism & \\
\hline & $\begin{array}{c}\mathrm{V}_{5} \\
6\end{array}$ & extraversion & \\
\hline & $\mathrm{V}_{5}$ & agreeableness & \\
\hline
\end{tabular}

\subsection{Project Management Performance}

Project management should achieve a series of objectives for the project to be considered a success, from the perspective of whoever is receiving the project's results. Measuring the project's success is not trivial, and depending on who is analyzing the project, it can be viewed differently depending on the time (Davis, 2017).

Project success is considered different from project management success (Anantatmula, 2015). Overall objectives like organizational impacts, stakeholder satisfaction, are measures of project success. In contrast, it measured project management success against the traditional measures of performance, such as completing project compliance with the schedule, the budget, the scope, and compliance with the quality requirements. (Kerzner, 2016). This study focuses on analyzing indicators of project management success that implies in the project's performance.

According to Kerzner (2016), schedule management enables the project to be completed within the deadline. Cost management includes, among other activities, cost control that allows finishing the project as close to the initial budgeted amount as possible, and quality control is directly related to compliance with the requirements and customer satisfaction. PMI (2017) states that managing the scope includes activities that aim to ensure that the project delivers all agreed-upon requirements.

Many studies are based on these four primary factors to highlight project management success (Anantatmula, 2015). In this study, it discussed these four factors form the project performance construct in the proposed theoretical model. Table 4 describes the project management performance. 


\section{Table 4}

Project Management performance

\begin{tabular}{|c|l|l|c|}
\hline \multicolumn{2}{|c|}{ Topic } & \multicolumn{1}{|c|}{ Performance } & Authors \\
\hline \multirow{4}{*}{$\begin{array}{c}\text { Overall } \\
\text { performance }\end{array}$} & Scope & Projects achieved the required scope. & \\
\cline { 2 - 3 } & Cost & Projects achieved the cost initially set. & \\
\cline { 2 - 3 } & Quality & $\begin{array}{l}\text { Projects achieved the required quality } \\
\text { goals. }\end{array}$ & $\begin{array}{c}\text { Anantatmula (2015); PMI } \\
\text { (2017) }\end{array}$ \\
\cline { 2 - 3 } & Time & Projects delivered on time. & \\
\hline
\end{tabular}

\section{Methodological Procedures Variable Selection and Reduction}

\subsection{Variable Selection and Reduction}

One of the most critical steps in quantitative methods is the choice of variables. A variety of statistical methods support researches on the variable selection that involves maximizing or minimizing the efficiency of the model when add or drop variables from the analysis.

\subsection{Genetic Algorithm}

Genetic algorithms (GA) are probabilistic algorithms that emulate the biological evolution of a population by applying genetic operators to recombine individuals based on one or more quality functions (Cerrada et al., 2016). They are a stochastic optimization technique widely used in finding optimal or near-optimal solutions for problems (Huang, Wang, \& Jiang, 2019).

The implementation of a basic GA begins with the generation of a chromosome's population, which is typically random. These structures are subjected to genetic operators: selection, crossover, and mutation. These operators use a quality characterization assessment that will generate a natural process evolution of these individuals based on an evaluation function.

After the selection of the fittest individuals, the reproduction process is performed. In this process, there is a crossover of two individuals who bear children that will be part of the next generation. This effect reproduces continuously until the process reaches the defined stopping point. A mutation creates diversity through a random change of genes during the reproduction process. Diversity helps in the search for increasingly fit individuals, as occurs in nature. 


\subsection{Multiobjective Optimization}

A basic GA evaluate the evaluation function using a single objective. In this study, the observation of a single objective is not sufficient to find a satisfactory solution because, with every generation, the influence of the genes will have to be simultaneously verified and represent the PM with the lowest number of genes possible. Therefore, there are two objectives: (1) the smallest number of genes that (2) best explain the phenomenon.

For simultaneous multiobjective optimization, GA evaluates the objectives together, and the trade-offs are analyzed until one finds the solution that meets both criteria simultaneously (Pilko, Mandžuka, \& Barić, 2017).

There are a few multiobjective GAs in the literature. The non-dominated sorting GA (NSGA and NSGA II), the Strength-Pareto evolutionary algorithm (SPEA and SPEA II), and the Pareto-archived evolution strategy (PAES) can be highlighted, among others. We selected the NSGA-II algorithm proposed by Kalyanmov et al. (2002) (Kamjoo et al., 2016) for this study due to its ability to maintain a better distribution of solutions, converging to an optimal solution in less time compared to the others.

\subsection{Operationalization of Theoretical Constructs}

We based this exploratory study on a theoretical model represented in Figure 3, in which project manager Behavior, Skills, and Knowledge compose the Project Manager Competencies, as described in section 2.2 . 


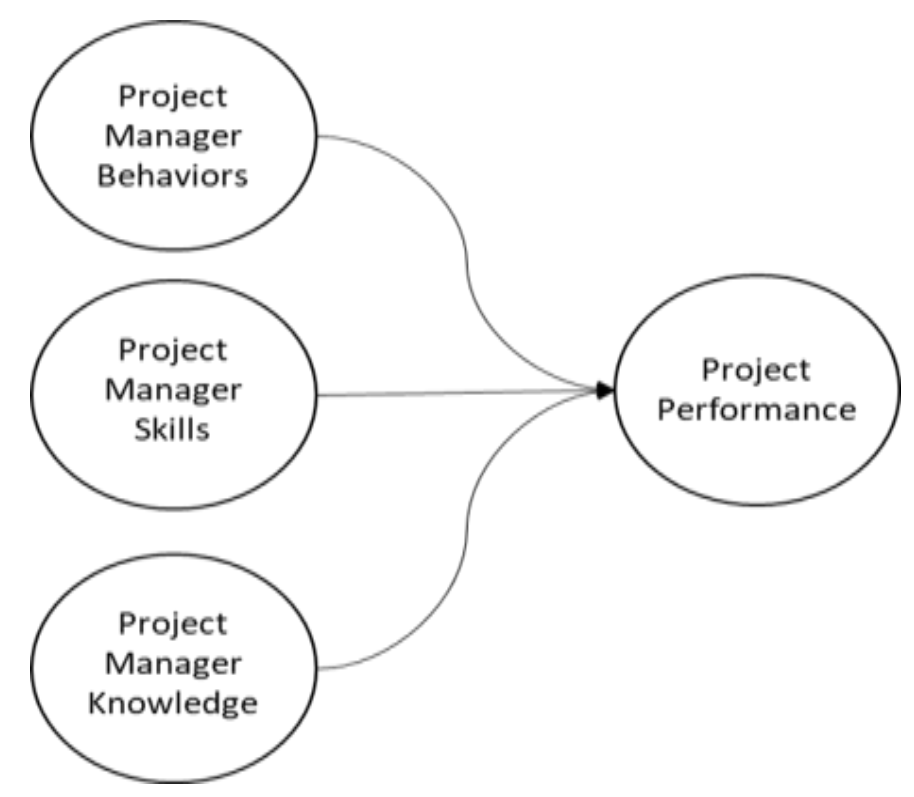

Figure 3. Theoretical model.

The first exogenous construct represents Knowledge, with 13 possible variables described in Table 1. The second exogenous construct is Skills, with 20 possible variables showed in Table 2. Finally, the third exogenous construct represents Behaviors, which includes 24 possible variables, as summarized in Table 3.

The endogenous construct of project performance composed of the four main factors of successful projects (cost, scope, quality, and time), as described in section 2.4.

Several studies have linked project performance and competencies (Kerzner, 2016; Anantatmula \& Rad, 2019; Haggerty, 2000; Lampel, 2001; Brill et al., 2006; Fisher, 2011; Moura, Carneiro, \& Diniz, 2018), providing theoretical support for the proposed model.

\subsection{Data Collection}

The data collection used an online questionnaire divided into four parts. The first three parts had questions about the knowledge, skills, and behavior of the PM (Tables 1,2,3). The fourth and final part of the questionnaire consisted of questions about the performance (Table 4). The variables described in the theoretical framework connect to a question in the questionnaire. All questions used a 5-point Likert scale, which has worked well in similar studies (Hair et al., 2009). 
The survey involved professionals who worked in project management and are part of project management associations (PMI) in the states of south-eastern Brazil. As an exploratory study, the sampling technique used in this study was the non-probability sampling.

It was collected a total of 184 responses from professionals in project management and experts in projects between 25 and 60 years of age; $96 \%$ had a university degree, and they were from the areas of information technology (66\%), engineering (23\%) and management (6\%). The majority of who responded to the survey $(79 \%)$ had managed projects for over five years.

\subsection{Preliminary Data Analysis}

Before submitting the data to the GAs, a preliminary analysis conducted to ensure compliance with the assumptions of multiple linear regression, the strategy chosen for the chromosomes' selection. First, a normality test performed on all variables using the Shapiro-Wilk test, which, according to Razali and Wah (2011), is the most powerful test for all types of distribution. The indicators showed the normal behavior of the data.

The adjusted value of $\mathrm{R}^{2}$ for the model was 0.274 , demonstrating that there is an association between the independent (competence) and dependent (performance) variables. The three constructs were considered significant: knowledge, behavior $(\mathrm{p}<0.1)$, and skills $(\mathrm{p}<$ $0.05)$. Multicollinearity was also verified to validate that none of the independent variables is correlated, VIF - variance of inflation factor of 0.2 to 5.0, according to Hair et al. (2009).

\subsection{Implementation of the NSGA-II Genetic Algorithm}

The NSGA-II algorithm was implemented using Matlab (MATLAB, 2020), applying statistical and GA toolboxes. The scripts used in this article were based on Deb et al. (2002).

\subsection{Assembling the Chromosome}

The biological chromosome consists of genes responsible for individual characteristics. Through an analogy, it is possible to construct an artificial chromosome containing the characteristics of the PM. The chromosome of the PM has 57 variables described in Tables 1, 2 , and 3. Thus, each of these characteristics corresponds to a gene in the chromosome. 


\subsection{Implementation Strategy}

With the chromosome defined, the next step is to define the implementation strategy and evaluation functions. Several studies use GAs and statistical techniques. Therefore, it becomes necessary to use a selection model with cross-validation that separates the sampling databases into training and validation/testing to select the variables (Kramer, 2017).

As noted above, the strategy adopted in this study to define the most suitable chromosome sequence based on Kramer (2017), involving multiple linear regression (MLR) using the root mean square error of prediction (RMSEP). It chose MLR because the model has only one dependent variable and several independent predictive variables (Hair et al., 2009); it uses the metric measurement scale aligned with this study objective. The regression coefficients and their explanatory power based on the coefficient $\left(\mathrm{R}^{2}\right)$ generate a function that seeks to predict project manager performance.

The RMSEP is defined based on Equation 1. The regression equation generated previously with (n) as the size of the database calculus the error between the actual response (y1) and the predicted response (y2).

Equation 1:

$$
R M S E P=\sqrt{\sum_{i=1}^{n}(y 1-y 2)^{2} / n}
$$

Note: Source: Broadhurst et al. (1997, p. 75).

The evaluation functions used were the result of the RMSEP equation (prediction error) and the individual's number of variables (chromosome). The number of variables is calculated when validating the chromosome. It is considered only variables with genes equal to 1 (one).

\subsection{Division of Databases}

To implement the NSGA-II, we followed the model's strategy of cross-validation selection (Broadhurst et al., 197) in which splits the database of 184 responses into two databases, one 
for calibration and the other for testing. There is no single definition for the proportionality of the size of the calibration and test databases; the related literature differs on this point (Galvão et al., 2005). For this study, we used the distribution of $60 \%$ for training and $40 \%$ for validation and testing.

For the division of the database, it applied the Kennard-Stone (KS) algorithm; this method intent to evenly distribute the data, maximizing the Euclidean distances between the response vectors.

\subsection{NSGA-II Algorithm Adapted for Binary Genes}

The traditional NSGA-II algorithm works with integers and real numbers and is not prepared to work with binary numbers. The algorithm had to be adapted under the following six steps:

1. It begins with a random population of 100 chromosomes (individuals) with 57 genes of the model represented by "0s" and "1s", where 0 (zero) means "off," i.e., the gene should not be part of the calculation, and 1 (one) means "on," i.e., the variable should be part of the calculation.

2. For each individual in the population, the algorithm performs the following:

a. It calculates the regression coefficient $\beta$ for the on genes;

b. It calculates the predicted $\mathrm{Y}$ using the coefficient $\beta$ (MLR);

c. It calculates the RMSEP between the predicted Y and the validation base;

d. It counts the number of genes of the individual;

3. It uses the multiobjective "decision-maker" to select the two individuals with the lowest RMSEP of prediction and the lowest number of variables.

4. It conducts the crossover with a $90 \%$ probability factor of these two individuals, considering the mutation factor of $20 \%$, generating new, fitter individuals. The crossover is performed using the fusion of the characteristics of two individuals to form two new individuals, each new individual having $50 \%$ of the genes of each individual. After the creation of two new individuals, the genes that underwent mutation are reversed, that is, zero becomes a one and vice versa.

5. It includes these new individuals in the population.

6. It repeats the process until saturation.

After 1000 generations observed that the algorithm already reached an optimal solution and could not significantly evolve the individuals of the population. The choice of the population of 100 individuals was also made empirically because, with smaller populations, convergence was very slow, and larger populations demanded more processing time for the 
GA. The probability factors of crossover (90\%) and mutation (20\%) were those with the highest convergence rate by generation.

Figure 4 shows the NSGA-II converging after 1000 generations. The first represents the first generation of randomly generated chromosomes, and the second graph shows the distribution of chromosomes after the evolution process.

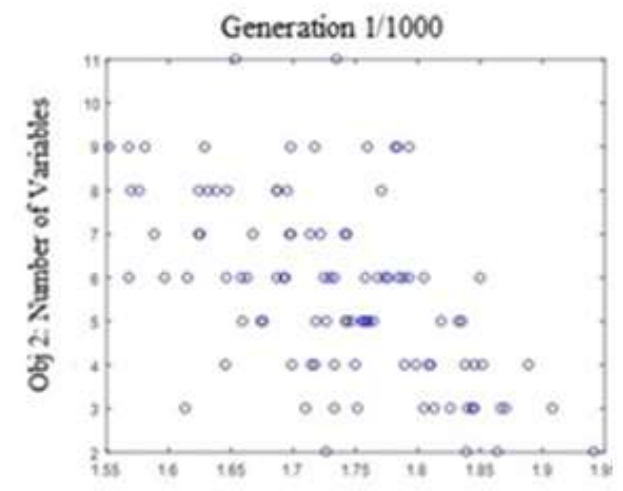

Obj 1: Error

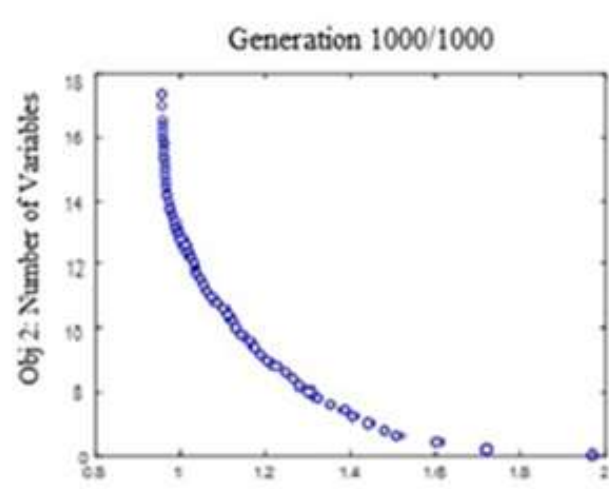

Obj 1: Error

Figure 4. Optimization of NSGA-II

\section{Results}

The NSGA-II algorithm performed five times, once for each pillar of project performance, i.e., cost, time, scope, and quality and once for the overall performance. After processing, the NSGA-II algorithm returned a set of solutions with 100 different chromosomes (population size). To select the final individual from the 100 possibilities, we performed the signed-rank Wilcoxon test, and a nonparametric hypothesis test used when comparing two samples related in a single sample to assess whether the rank of the population means is different (Wang \& Wang, 2018).

After the selection of chromosomes, it performed a new linear regression with only the selected variables to check whether the original values had changed after the withdrawal of the variables that were not selected. Table 5 shows that the $\mathrm{R}^{2}$ value decreased from the original value of 0.274 to 0.202 . 


\section{Table 5}

Preliminary Analysis of the Data.

\begin{tabular}{lc}
\hline Construct & Beta \\
\hline Constant** & 1.865 \\
Knowledge* & 0.100 \\
Skills** & 0.299 \\
Behavior* & 0.114 \\
\hline $\mathrm{R}^{2}=0.202$ & \\
\hline
\end{tabular}

Note: $* * p<0.05 ; * \mathrm{p}<0.1$

As a result of the regression, the skills partly explain the overall project performance. It excluded 15 variables from 57 initially studied (26.31\% considered irrelevant).

Thus, hypothesis $\mathrm{H}_{1}$ of this study was not rejected; therefore, there is a core of PM competencies that have greater relevance in the performance of the project.

Tables 6, 7, and 8 show the details of variables that comprise all constructs operationalized by the GA for each performance measured.

\section{Table 6}

PM Competencies for knowledge

\begin{tabular}{|c|c|c|c|c|c|c|c|c|c|c|c|c|c|c|}
\hline & $\begin{array}{l}\mathrm{V} \\
1\end{array}$ & $\begin{array}{l}\mathrm{V} \\
2\end{array}$ & $\begin{array}{l}\mathrm{V} \\
3\end{array}$ & $\begin{array}{l}\mathrm{V} \\
4\end{array}$ & $\begin{array}{l}\mathrm{V} \\
5\end{array}$ & $\begin{array}{l}\mathrm{V} \\
6\end{array}$ & $\begin{array}{l}\mathrm{V} \\
7\end{array}$ & $\begin{array}{l}\mathrm{V} \\
8\end{array}$ & $\begin{array}{l}\mathrm{V} \\
9\end{array}$ & $\begin{array}{l}\mathrm{V} \\
1 \\
0 \\
\end{array}$ & $\begin{array}{l}\mathrm{V} \\
1 \\
1 \\
\end{array}$ & $\begin{array}{l}\mathrm{V} \\
1 \\
2 \\
\end{array}$ & $\begin{array}{l}\mathrm{V} \\
1 \\
3 \\
\end{array}$ & Total \\
\hline Time & $\bullet$ & & & & & & & & & & & & & 1 \\
\hline Cost & $\bullet$ & $\bullet$ & & $\bullet$ & & $\bullet$ & & & & & $\bullet$ & & $\diamond$ & 6 \\
\hline Quality & $\bullet$ & $\bullet$ & & & & & $\bullet$ & & $\diamond$ & & & & & 4 \\
\hline Scope & & & & & & & & $\diamond$ & $\bullet$ & & & $\bullet$ & $\diamond$ & 4 \\
\hline Performance & & & & & & & & $\bullet$ & $\diamond$ & & & $\bullet$ & $\bullet$ & 4 \\
\hline Excluded & & & 一 & & 一 & & & & & 一 & & & & 3 \\
\hline Total & 3 & 2 & 0 & 1 & 0 & 1 & 1 & 2 & 3 & 0 & 1 & 2 & 3 & \\
\hline
\end{tabular}

Note: $\bullet$ : Included; - : Excluded.

Table 6 shows which variables form the knowledge construct for each of the performances measured. Three variables, i.e., $\mathrm{V}_{1}$ (project estimates), $\mathrm{V}_{9}$ (the decision-making process outside the organization) and $\mathrm{V}_{13}$ (computer use), are repeated in three constructs of performance: time $\left(\mathrm{V}_{1}\right)$, cost $\left(\mathrm{V}_{1}\right.$ and $\left.\mathrm{V}_{13}\right)$, quality $\left(\mathrm{V}_{1}\right.$ and $\left.\mathrm{V}_{9}\right)$, the overall performance $\left(\mathrm{V}_{9}\right.$ and $\left.\mathrm{V}_{13}\right)$, and scope $\left(\mathrm{V}_{13}\right)$. Another three, i.e., $\mathrm{V}_{2}$ (the techniques and tools for project management), 
$\mathrm{V}_{8}$ (the partners), and $\mathrm{V}_{12}$ (multidisciplinary subjects), are part of overall performance and scope performance. "Knowledge" is emphasized in cost performance, which incorporates a total of six variables; at the other extreme, "knowledge" for time performance is influenced by only one of the variables of this competence.

Of all the variables studied in the literature for knowledge, three (23.07\%) were not relevant in this study: project domain, measures of success, and politics or culture outside the organization. The project domain refers to technical knowledge about the development by the project of product or service. Its exclusion can be explained by PMI (2017), which states that a PM need not know the domain but only about the techniques of project management. The culture and politics outside the organization may not have been relevant because the vast majority of respondents work in private companies ( $86 \%$ of the total), and typically, knowledge about culture and politics is much more necessary in public projects. The exclusion of the measures of project success contradicts the results of Brill et al. (2006), who rated the importance of this knowledge tenth in a set of competencies for project success.

Table 7 consolidates the variables selected for each of the performances measured for the skills construct. We note that the competence "Knows how to recognize a problem" was selected four times in the performance constructs, indicating its influence on all of the measured performance pillars. A more significant number of different variables influence Quality and scope performance in comparison with the skills construct. The distribution of variables between the different performances was balanced, and only one, "Knows how to negotiate and persuade" $(1.75 \%)$, was not relevant in any of the dimensions of performance analyzed, which contradicts one of the skills included in the Brazilian Classification of Occupations - CBO.

Table 7

PM Competencies for skills

\begin{tabular}{|c|c|c|c|c|c|c|c|c|c|c|c|c|c|c|c|c|c|c|c|c|c|}
\hline & V & V & V & V & V & V & V & V & V & V & V & V & V & V & V & V & V & V & V & V & Total \\
\hline & 1 & 1 & 1 & 1 & 1 & 1 & 2 & 2 & 2 & 2 & 2 & 2 & 2 & 2 & 2 & 2 & 3 & 3 & 3 & 3 & \\
\hline & 4 & 5 & 6 & 7 & 8 & 9 & 0 & 1 & 2 & 3 & 4 & 5 & 6 & 7 & 8 & 9 & 0 & 1 & 2 & 3 & \\
\hline Time & & & & $\diamond$ & & & & & & 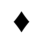 & & 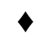 & & $\checkmark$ & & & $\bullet$ & & $\bullet$ & & 6 \\
\hline Cost & & & $\diamond$ & $\bullet$ & & & & & & & & $\bullet$ & & $\bullet$ & & & & $\bullet$ & $\bullet$ & & 6 \\
\hline Quality & $\bullet$ & $\bullet$ & & $\bullet$ & & $\bullet$ & $\bullet$ & & $\bullet$ & $\bullet$ & & & & $\bullet$ & & & & & & $\diamond$ & 9 \\
\hline Scope & $\bullet$ & $\bullet$ & & & $\bullet$ & & & & & & & & & $\bullet$ & & $\diamond$ & $\bullet$ & $\diamond$ & & $\bullet$ & 8 \\
\hline Perform. & & & & & & 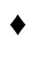 & & & & & $\bullet$ & & $\bullet$ & & & & $\bullet$ & & $\bullet$ & & 5 \\
\hline Excluded & & & & & & & & - & & & & & & & & & & & & & 1 \\
\hline Total & 2 & 2 & 1 & 3 & 1 & 2 & 1 & 0 & 1 & 2 & 1 & 2 & 2 & 4 & 1 & 1 & 3 & 2 & 3 & 2 & \\
\hline
\end{tabular}

Note: $\diamond$ Included; -: Excluded. 
Table 8 shows the distribution of the variables for the behavior construct linked to the five types of performance measurement. The variables from this construct were less relevant to the GA. It disregarded a total of 11 variables in either model ( $47.8 \%$ of the variables). None of the variables appeared more than twice in the different constructs, which indicates a relative scattering of relevant variables. Time performance had a more significant number of variables related to the selected behavior (four). The others had two or three variables selected, showing a relative balance. With these results, a few aspects related to behavior influence project performance.

\section{Table 8}

PM Competencies for behavior

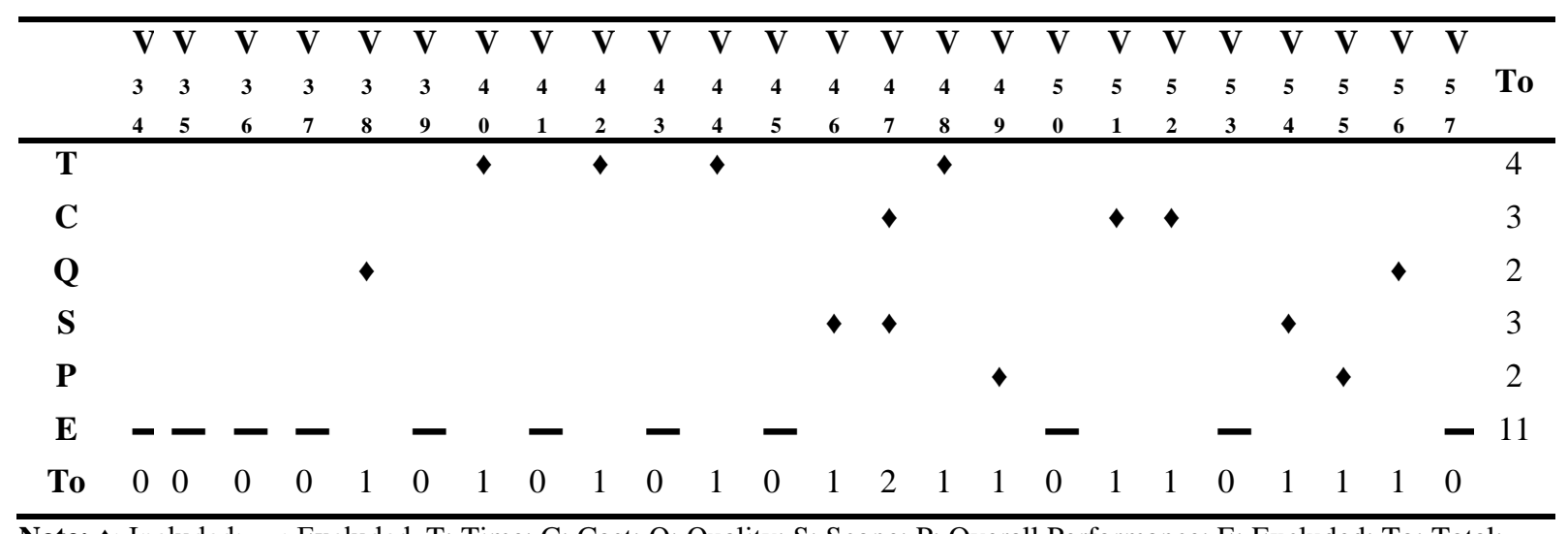

Note: $\$$ : Included; —: Excluded. T: Time; C: Cost; Q: Quality; S: Scope; P: Overall Performance; E: Excluded; To: Total;

Table 9 shows the distribution of the variable for each model related to each type of performance.

Table 9

Variable distribution for each model

\begin{tabular}{lcc}
\hline Variables & Number of variables & Percentage (\%) \\
\hline Cost & 16 & 28.07 \\
Quality and Scope & 15 & 26.32 \\
Time & 11 & 19.30 \\
Overall Performance & 11 & 19.30 \\
\hline
\end{tabular}




\section{Discussion and Analysis}

\subsection{Overall Performance}

For the overall performance model, the $\mathrm{R}^{2}$ value, before the execution of the GA, was 0.274. After the execution and assembly of the simplified model, it showed an $\mathrm{R}^{2}$ value of 0.202. Even with the reduction of variables, the explanatory power did not show a significant decrease. Moreover, it is relevant to emphasize that project performance was measured by the proxy project performance, and therefore, project performance cannot be fully explained only by the direct action of the PM because many other factors influence the project outcome (Moura, Carneiro \& Diniz, 2018).

In the model of overall performance, the skills construct has a higher regression coefficient (0.299) and, therefore, a higher weight in the equation. Thus, when addressing the competencies of a PM, one should pay attention to the fact that investment in skills will bring higher results in the manager's performance. Next, the behaviors construct had a higher regression coefficient $(0.114)$ than the knowledge construct $(0.100)$; thus, it can be considered the second priority in human resource development in project management.

It is interesting to note that much of the training and certification offered for PMs by associations and specialized courses focus on knowledge to improve the project's performance and results (Crawford, 2005). However, the study's results show that skills and behaviors have a higher effect, which is in line with the behavioral excellences defended by Kerner (2017) and Crawford (2005, p.7), who identified no significance in the relationship between the management standards known and disseminated by these associations and project performance.

The skills selected for the PM were "knows how to manage tasks effectively," which is in line with the technical skills described by Lampel (2011, p.475) and Fotwe and McCaffer (2000, p.121); "knows how to be guided by goals" is a competence defended by El-Sabaa (2001); "knows how to evaluate complex situations," which corroborates the core competencies described by Lampel (2011); "knows how to communicate verbally," addressed by El-Sabaa (2001); and "knows how to communicate effectively," i.e., communication so that those involved achieve the necessary vision, as argued by Fotwe and McCaffer (2000).

The behaviors that compose the model are "emotional stability," which is one of the personality traits described by Soto and John (2009), and "shares credit for the success," which is one of the ten most essential competencies defended in work by Brill et al. (2006). 
The types of knowledge included in the model that can bring more consistent results for PM performance are as follows: "multidisciplinary topics," which Lampel (2001) includes as one of the critical competencies for the effective implementation of projects; "knows the partners," which, according to Lampel (2001) and Brill et al. (2006), is essential for excellent project performance; Brill et al. (2006, p.33) also includes knowledge about the "decisionmaking process outside the organization" as necessary knowledge for the PM; and, finally, ElSabaa (2001) considers that knowledge of "computer use" is indispensable to project management.

The profile of the PM formed from overall performance shows a tendency of commitment and control based on the information because these show characteristics that allow the PM to be guided by goals have an accurate view of project progress through communication, exercise effective control through multidisciplinary knowledge and computer use as well as close relationships with partners, stakeholders, and the external environment.

The research results and data analysis show evidence that PMs with the best results have specific competencies, which are essential indicators in directing efforts in training and improving maturity in project management to obtain better results in project performance.

\subsection{Specific Types of Performance}

Overall performance is the most important construct because there is no way to improve overall performance without improving at least one of the four pillars of performance. However, in cases where the problem in performance is specific, one can invest in certain characteristics that bring specific, direct results. For example, an organization may be having recurrent delays in its projects, but without cost, scope, and quality falling outside of the plan. In these cases, directly investing in time-related competencies may be the best decision.

The results show that there are differences in skills, knowledge, and behaviors for each of the pillars (Tables 6, 7, and 8), giving indications that one should invest in different competencies for each of these.

Related to time performance are the following: "logical reasoning," "communication," "recognition of and guidance through a problem," and "focus on the customer," which shows the "ability to recover from unexpected events" and "assertive responses at critical moments." "Communication and knowledge of estimates" are indicative of the ability to handle schedules, 
which can be critical for re-planning and the control of project deadlines. Behaviors such as "persistence," "involvement in other areas," and "teamwork" lead to the capacity to interact and search for goals. Kerzner (2016) states that the PM must demonstrate solid behavioral skills for both internal and external integration and should know how to manage complexity, demonstrating tenacity, perseverance, and quick and assertive responses when faced with problems.

Related to performance in quality, we note the following: the "use of tools and project management techniques," "knows how to learn," "innovate," "guidance and recognition of problems," "effective management," "motivation," and "logical reasoning," which show evidence of a profile of close control and the tendency to test new solutions and innovate. Kerzner (2016) states that the pursuit of excellence includes measures to be adopted by PMs, such as working creatively and innovatively whenever necessary.

Related to performance in cost, it highlighted: "graphic communication" and "verbal expression," "logical and analytical reasoning," "computer use," "flexibility and organization," and "estimates and proposals," which give evidence of a profile with the knowledge to handle numbers, an organization to keep track of costs, and flexibility in addressing problems. These competencies align with those in the studies by Brill et al. (2006), El-Sabaa (2001), Lampel (2001), and Fotwe and McCaffer (2000).

Related to performance in scope are the following: "knows how to listen," "verbal expression," "effective surveying of tasks," "sharing requirements with those involved," "multidisciplinary knowledge," "innovation in the composition of scope," and "adaptation to changes during the project." These competencies enhance the ability to control the scope even with problems. Isik et al. (2009) highlight the need to manage knowledge and project documents to meet the satisfaction of the customer. Crawford (2005) states that the monitoring and control of scope reduce disparities and contribute to the project's high performance.

Through specific problems, the competencies described above are a guide for prioritizing training and skills efforts, which can improve the results in specific pillars of projects.

\section{Final Considerations}

This study has explored the competencies of the PM and unveiling its core ones, selecting relevant variables and the indication of which competencies may influence the project 
performance. It provided evidence that it is possible to improve the results of projects by investing promptly in the development of certain types of skills, behaviors, and knowledge or by hiring professionals with this profile. The findings can serve as a guide for human resources to prioritize efforts and investment and can also serve as an indicator in the selection of new professionals.

The study also showed that adding new knowledge or PMs without investing in their skills and behaviors is not a good strategy. The evidence shows that skills and behaviors influence performance more significantly than the professionals' knowledge.

This paper contributes to the scientific and organizational field by conducting a quantitative study and providing results around the Project Management area and by seeking answers to a problem in organizations. As an additional contribution, the study showed the Genetic Algorithm and demonstrated the feasibility of its application to the research in the social sciences area, mainly in situations in which there are many variables involved. The GA has proven to be a powerful tool for variable selection that can be applied in situations where the number of variables to be analyzed is vast, or optimization is needed to understand a phenomenon or its solution.

A limitation of this study is related to the study respondents, who were mostly professionals from the area of information technology, which may have caused a bias that can somehow make it difficult to generalize the model.

Future studies can test the generated simplified model with another dataset. These studies can help refine this research through the empirical validation of the final proposed model.

\section{References}

Ajzen, I. (2005). Attitudes, personality, and behavior. Open University Press, MaGrawHill Press, England.

Anantatmula, V. S. (2015). Strategies for Enhancing Project Performance. Journal of Management Engineering, 31(6), 1-8.

Anantatmula, V. S.; Rad, P. F. (2018). Role of Organizational Project Management Maturity Factors on Project Success, Engineering Management Journal, 30(3): 165178.

Basso, K.; Laimer, C.G.; Baseggio, H.W. (2015). Personalidade e Boca-a-Boca: Proposições de Pesquisa. Pensamento Contemporâneo em Administração, 9(2), 17-29. 
Boyatzis, R. E., Goleman, D., Gerli, F., and Bonesso, S. (2019). Emotional and Social Intelligence Competencies for Project Management. In Cognitive Readiness in Project Teams, 171-195. Productivity Press.

Brill, J.M.; Bishop, M.J.; Walker, A.E. (2006). The competencies and characteristics required of an effective project manager: a web-based Delphi study. Association for Educational Communications and Technology, 54(2):115-140.

Broadhurst, D.; Goodacre, R.; J., Alun; Rowland, J.J.; Kell, D.B. (1997). Genetic algorithms as a method for variable selection in multiple linear regression and partial least squares regression, with applications to Pyrolysis mass spectrometry. Analytica Chimica Acta, 348(1-3), 71-86.

Buchaman, D., Huczynski, A. (1997). Organizational behaviour: an introductory text, 3ed. Prentice Hall.

CBO. (2019). Classificação Brasileira de Ocupações. http://www.mtecbo.gov.br/cbosite/pages/home.jsf. Accessed 25 August 2019.

Cerrada, M., Zurita, G., Cabrera, D., Sánchez, R. V., Artés, M., and Li, C. 2016. Fault diagnosis in spur gears based on genetic algorithm and random forest. Mechanical Systems and Signal Processing, 70, 87-103.

Chen, C.; Tiong, L. K.; Chen, I. (2019). Using a genetic algorithm to schedule the spaceconstrained AGV-based prefabricated bathroom units manufacturing system. International Journal of Production Research, 57(10), 3003-3019.

Crawford, L. (2005). Senior management perceptions of project management competence. International Journal of Project Management, 23(1): 7-16.

Credé, M.; Harms, P.; Niehorster, S., Graye-Valentine, A. 2012 An Evaluation of the Consequences of Using Short Measures of the Big Five Personality Traits. Journal of Personality and Social Psychology, 102 (4): 874-888.

Davis, K. (2017). An empirical investigation into different stakeholder groups perception of project success. International Journal of Project Management, 354, 604-617.

De Raad, B., and Mlacic, B. (2015). Big five factor model, theory and structure. International encyclopedia of the social and behavioral sciences, 2(2), 559566.

Deb K, Pratap A., Agarwal S, et al. 2002. A fast and elitist multiobjective genetic algorithm NSGA-II[J]. Evolutionary Computation. 6(2): 182-197.

Durand, T. (2015). L'alchimie de la compétence. Revue Française de Gestion, 41(253), 261-292, Lavoisier.

Dutra, J. S. (2001). Gestão do desenvolvimento e da carreira por competência: gestão por competências: um modelo avançado para o gerenciamento de pessoas. São Paulo: Editora Gente.

El-Sabaa, S. (1999). The skills and career path of an effective project manager. International Journal of Project Management, 19(8): 1-7.

Erthal, T.C.S. (1984). Personalidade e mudança de atitude. Ar. Bras. Psic. Rio de Janeiro, 36 (3), 90-98.

Fleury, M.T.L.; Fleury, A. (2001). Construindo o conceito de competência. RAC-Revista de Administração Contemporânea. Edição Especial, 5(SPE), 183-196.

Fisher, Eddie. (2011). What practitioners consider to be the skills and behaviours of an effective people project manager. International Journal of Project Management, 29 (8), 994-1002.

Fotwe, F.T. Edum; Mccaffer, R. (2000). Developing project management competency: perspectives from the construction industry. International Journal of Project Management, 18 (2), 111-124. 
Galvão, Roberto K.H.; Araujo, M.C.U.; Jose, Gledson E. J.; Pontes, Marcio J. C.; Silva, Edvan C.; Saldanha, Teresa C. B. (2005). A method for calibration and validation subset partitioning. Talanta, 67 (4), 736-740.

Goldberg, Lewis. (1990). An Alternative "Description of Personality": The big-five factor structure. Journal of Personality and Social Psychology, 59 (6), 1216-1229.

Haggerty, Nicole. (2000). Understanding the link between IT project manager skills and project success research in progress. SIGCPR - Evanston Illinois, USA.

Hair, Joseph F. Jr; Black, Willian C.; Babin, Barry J.; Andeeerson, Rolph E.; Tathan, Ronald L. (2009). Analise multivariada de dados. 6ed. Bookman.

Huang, J.; Wang, L.; Jiang, Z. (2019). A method combining rules with genetic algorithm for minimizing makespan on a batch processing machine with preventive maintenance. International Journal of Production Research, 58(13), 1-17.

Isik, Z., Arditi, D., Dikmen, I., Birgonul, M. T. (2009). Impact of corporate strengths/weaknesses on project management competencies. International Journal of Project Management, 27(6), 629-637.

Judge, T.A., Zapata, C.P. (2015). The Person-situation Debate Revisited: Effect of Situation Strength and Trait Activation on the Validity of Big Five Personality Traits in Predicting Job Performance. Academy of Management Journal, 58 (4): 1149-1179.

Kalyanmov, D.; Pratap, A.; Agarval, S.; Meyarivan, T. (2002). A Fast and Elitist Multiobjective Genetic Algorithm: NSGA-II. IEEE Transactions on Evolutionary Computation, 6(2), 182-197.

Kamjoo, A., Maheri, A., Dizqah, A. M., and Putrus, G. A. (2016). Multiobjective design under uncertainties of hybrid renewable energy system using NSGA-II and chance constrained programming. International Journal of Electrical Power and Energy Systems, 74, 187-194.

Kramer, O. (2017). Genetic algorithm essentials (v. 679). Springer: Cham, Switzerland.

Kerzner, H. (2019). Using the Project management maturity model: strategic planning for project management. 3 ed. John Wiley and Sons, inc. New Jersey.

Kerzner, H. (2016). Gestão de Projetos: As melhores práticas. 3 ed. Artmed Editora S.A. São Paulo.

Kichenham, B. (2004). Procedures for Performing Systematic Reviews (pp. 33). Eversleigh, NSW: Software Engineering Group Department of Computer Science, Keele University.

Lampel, J. (2001). The core competencies of effective project execution: the challenge of diversity. International Journal of Project Management. 19.

Le Boterf, (2003). Desenvolvendo a competência dos profissionais. Porto Alegre: Bookman-Artmed.

Leutner, F.; Ahmetoglu, G.; Akhtar, R.; Chamorro-Premuzic, T. (2014). The relationship between the entrepreneurial personality and the Big Five personality traits. Personality and Individual Differences, 63, 58-63.

Marchiori, M.; Bastos, A.R.S. \& Moraes, M. M. (2015). A Ouvidoria como processo de construção de conhecimento. In: IASBECK, L. C. (Org.). Ouvidoria: mídia organizacional. Porto Alegre: Sulina, 60-80.

MATLAB 2020. https://www.mathworks.com/products/matlab.html. Accessed 25 July 2020.

Moura, R. L., Carneiro, T. C. J., \& Diniz, B. D. (2018). Influence of the project manager's personal characteristics on project performance. Gest. Prod, 25(4), 752- 763. 
Moura, R. L., Carneiro, T. C. J., Lemos Dias, T., \& Oliveira, B. S. (2019). Personality traits of project managers: differences in knowledge, experience, and business sector. Revista de Administração da UFSM, 12(4): 767-784.

Nicholson, N. (2000). Executive instinct: managing the human animal in the information age. Hardcover - New York.

Pilko, H., Mandžuka, S., and Barić, D. (2017). Urban single-lane roundabouts: A new analytical approach using multi-criteria and simultaneous multiobjective optimization of geometry design, efficiency and safety. Transportation Research Part C: Emerging Technologies, 80(1), 257-271.

PMI. (2017). A Guide to the project management body of knowledge - Pmbok ${ }^{\circledR}$ Guide 6 Edition, Pennsylvania-USA.

Razali, N. M.; Wah, Y. B. (2011). Power comparisons of Shapiro-Wilk, KolmogorovSmirnov, Lilliefors and Anderson-Darling tests. Journal of Statistical Modeling and Analytics, 2(1): 21-33.

Saptoro, A.; Tadé, M. O.; Vuthaluru, H. (2012). A Modified Kennard-Stone Algorithm for Optimal Division of Data for Developing Artificial Neural Network Models. Chemical Product and Process Modeling, 7(1), 1934-2659.

Sbragia, R., Maximiano, A.C., Kruglianskas, I. (1986). O gerente de projetos: seu papel e habilidades, Revista de Administração, 21(3), 24-21.

Sliwoski, G., Kothiwale, S., Meiler, J., and Lowe, E. W. (2014). Computational Methods in Drug Discovery. Pharmacological Reviews, 66(1), 334-395.

Soto, C.J., John, O.P. (2009). Ten facet scales for the Big Five Inventory: Convergence with NEO PI-R facets, self-peer agreement, and discriminant validity. Journal of Research in Personality, 43(1), 84-90.

Thomas, J; Mengel, T. (2008). Preparing project managers to deal with complexity advanced project management education. International Journal of Project Management. 26(3), 304-315.

Yazici, H. J. (2018). Role of Organizational Project Maturity on Business Success: Last Five Years' Outlook and Beyond. In G. Silvius, and G. Karayaz (Eds.), Developing Organizational Maturity for Effective Project Management (pp. 43-54). Hershey, PA: IGI Global.

Zarifian, P. (2003). O modelo da competência: trajetória histórica, desafios atuais $\boldsymbol{e}$ propostas. São Paulo: Senac, 192.

Wang, C., Ji, Z., and Wang, Y. (2018). Many-objective flexible job shop scheduling using NSGA-III combined with multi-attribute decision making. Modern Physics Letters B, 32(34n36), 1840110, 1-8. 